\title{
RANCANG BANGUN ALAT UJI PPI CARD
}

\author{
Mohammad Iqbal \\ Teknik Elektro Universitas Muria Kudus \\ email: iqbal.umk@gmail.
}

\begin{abstract}
ABSTRAK
PPI Card biasanya digunakan dalam matakuliah praktek antarmuka dan kadang juga digunakan dalam proyek akhir mahasiswa. Karena seringnya digunakan dan atau kecerobohan mahasiswa dalam pemakaian, tak jarang komponen utama dalam PPI Card yaitu IC PPI 8255 rusak. Kerusakan yang sering dijumpai adalah kerusakan sebagian, artinya sebagian I/O berfungsi normal, sedangkan sebagian yang lainnya rusak. Kerusakan sebagiannya ini sering menipu dan mengacaukan kegiatan praktek mahasiswa, oleh karenanya IC PPI 8255 yang rusak ini harus segera diganti. Kerusakan sebagian ini lebih sukar dideteksi dari pada rusak secara keseluruhan. Untuk mendeteksi kerusakan PPI Card ini, diperlukan alat uji PPI Card yang dirancang dan dibuat khusus guna mengetahui rusak tidaknya IC pada PPI Card, baik rusak sebagian maupun rusak secara keseluruhan. Hasil Penelitian berupa hardware modul uji PPI Card beserta software-nya, yang telah diuji baik hardware maupun software, yaitu untuk port PPI sebagai input dan port PPI sebagai output. Pengukuran hardware dilakukan dengan mengukur tegangan tiap-tiap port PPI, sedangkan pengujian software, dilakukan dengan membandingkan tampilan pada program aplikasi (software) dengan kondisi LED pada modul uji (hardware).
\end{abstract}

Kata kunci: PPI Card, IC 8255, modul uji, LED

\begin{abstract}
PPI Cards are commonly used in the interface courses and sometimes also used in the studentfinal projects. Because of frequent use and or carelessness in the use of college students, often a main component in the Card PPI i.e. IC PPI 8255 is broken. The most often found broken is partially broken, meaning that most of the I / O function normally, while some others are broken. Broken IC is often deceptive and confusing practice of student activities, therefore IC PPI 8255 damaged should be replaced immediately. Broken IC is more difficult to detect than the totally broken. To detect the broken PPI Card, PPI Card is required test equipment are designed and manufactured specifically to determine whether faulty IC on PPI Card, either partially broken or totally broken. Research results are a Card PPI hardware test module with its software, which has been tested in both hardware and software, which is PPI port as the input port and PPI as an output port. Hardware measurements performed by measuring the voltage of each port PPI, while testing the software, made by comparing the appearance of the application program (software) to test the condition of the LEDs on the module (hardware).
\end{abstract}

Keywords: PPI Card, IC 8255, test module, LED

\section{PENDAHULUAN}

Pada sebuah komputer biasanya sudah dilengkapi dengan port-port yang memungkinkan komputer untuk 'berkomunikasi' dengan piranti eksternal, seperti printer, modem dan lain-lain. Port standar yang dimiliki oleh sebuah komputer adalah berupa port paralel dan port serial. Port paralel biasanya menggunakan label yaitu LPT1, LPT2, dan seterusnya, sedangkan port serial dengan label COM1, COM2, dan seterusnya.

Karena keterbatasan jumlah I/O (Input-Output), baik pada port paralel dan port serial, maka digunakan PPI Card. PPI Card adalah sebuah modul rangkaian elektronik yang menggunakan komponen utamanya berupa IC PPI 8255. Jumlah I/O yang dimiliki PPI Card adalah 24 buah.

Di dalam Laboratorium Teknik Elektronika, PPI Card sering digunakan sebagai salah satu modul praktikum untuk mata kuliah Praktek Teknik Antarmuka Mikroprosesor, selain port standar yang dimiliki komputer (port paralel dan port serial). Karena seringnya digunakan dan atau kecerobohan mahasiswa dalam pemakaian selama kegiatan praktek, tak jarang komponen utama dalam PPI Card yaitu IC PPI 8255 rusak. Kerusakan yang sering dijumpai adalah kerusakan sebagian, artinya sebagian I/O berfungsi normal, sedangkan sebagian yang lainnya rusak. Kerusakan sebagiannya ini sering menipu dan mengacaukan kegiatan praktek mahasiswa, oleh karenanya IC PPI 8255 yang rusak ini harus segera diganti. Kerusakan sebagian ini lebih sukar dideteksi dari pada rusak secara keseluruhan. Untuk mendeteksi kerusakan PPI Card ini, diperlukan alat uji PPI Card yang dirancang dan dibuat khusus guna mengetahui rusak tidaknya IC pada PPI Card, baik rusak sebagian maupun rusak secara keseluruhan.

\subsection{Slot Perluasan}

Sistem komputer IBM-PC XT/AT dirancang sebagai suatu sistem yang mudah untuk dikembangkan. Hal ini terlihat dengan adanya perluasan pada papan induk (motherboard) yang berfungsi untuk menghubungkan sistem komputer dengan peralatan-peralatan tambahan lain. Seperti misalnya untuk menghubungkan komputer dengan printer atau dengan monitor. 
Bagian perluasan komputer ini terdapat 8 buah slot yang masing masing terdiri dari 62 pin. Slot perluasan (ekspansi) terdiri dari dua buah sisi yaitu untuk sisi A dan sisi B pada komputer XT, sedangkan untuk AT ditambah dengan sisi C dan sisi D yang terdiri dari 36 Pin dan biasanya dikemas dalam keadaan menyambung. Untuk lebih jelasnya dapat dilihat dalam gambar 1 yang menunjukkan Slot perluasan pada Komputer IBM PC (Arianto, 1994).

\begin{tabular}{|c|c|c|c|c|c|}
\hline \multicolumn{2}{|c|}{ SISI B } & & \multirow{2}{*}{2} & \multicolumn{2}{|c|}{ SISI A } \\
\hline And & B1 & & & A1 & I/O CH READY \\
\hline Reset DRV & B2 & & 5 & A2 & D7 \\
\hline+5 Volt DC & B3 & 5 & 5 & A3 & D6 \\
\hline IRQ 2 & B4 & $\square$ & 4 & A4 & D5 \\
\hline-5 Volt DC & B5 & $\square$ & $\square$ & A5 & D4 \\
\hline DRQ 2 & B6 & 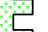 & 4 & A6 & D3 \\
\hline - 12 Volt DC & B7 & 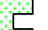 & 5 & A7 & D2 \\
\hline & B8 & 5 & 5 & A8 & D1 \\
\hline + 12 Volt DC & B9 & ᄃ & 4 & A9 & D0 \\
\hline GND & B10 & 5 & $\square$ & $\mathbf{A 1 0}$ & I/O CH READY \\
\hline MEMW & B11 & $\square$ & 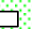 & A11 & AEN \\
\hline MEMR & B12 & 5 & - & $\mathbf{A 1 2}$ & A19 \\
\hline IOW & B13 & 5 & 5 & A13 & A18 \\
\hline IOR & B14 & 5 & E. & $\mathbf{A 1 4}$ & A17 \\
\hline DACK 3 & B15 & 5 & $\square$ & A15 & A16 \\
\hline DRQ 3 & B16 & 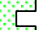 & 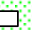 & A16 & A15 \\
\hline DACK 1 & B17 & 5 & 4 & A17 & A14 \\
\hline DRQ 1 & B18 & 5 & 5 & $\mathbf{A 1 8}$ & A13 \\
\hline DACK 0 & B19 & 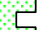 & 4 & A19 & A12 \\
\hline CLK & B20 & ᄃ & 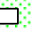 & $\mathbf{A 2 0}$ & A11 \\
\hline IRQ 7 & B21 & 5 & 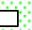 & A21 & A10 \\
\hline IRQ 6 & B22 & 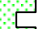 & $y$ & A22 & A9 \\
\hline IRQ 5 & B23 & 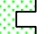 & - & $\mathbf{A 2 3}$ & A8 \\
\hline IRQ 4 & B24 & 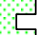 & 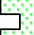 & A24 & A7 \\
\hline IRQ 3 & B25 & 5 & 5 & A25 & A6 \\
\hline DACK 2 & B26 & & 5 & A26 & A5 \\
\hline $\mathrm{T} / \mathrm{C}$ & B27 & & $y$ & A27 & A4 \\
\hline ALE & B28 & & 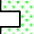 & A28 & $\mathbf{A 3}$ \\
\hline$+5 \mathrm{VDC}$ & B29 & & $\square$ & A29 & $\mathbf{A 2}$ \\
\hline OSC & B30 & $ᄃ$ & & $\mathbf{A 3 0}$ & A1 \\
\hline GND & B31 & 5 & & A31 & A0 \\
\hline & & & & SIS & KOMPONEN \\
\hline
\end{tabular}

(a)

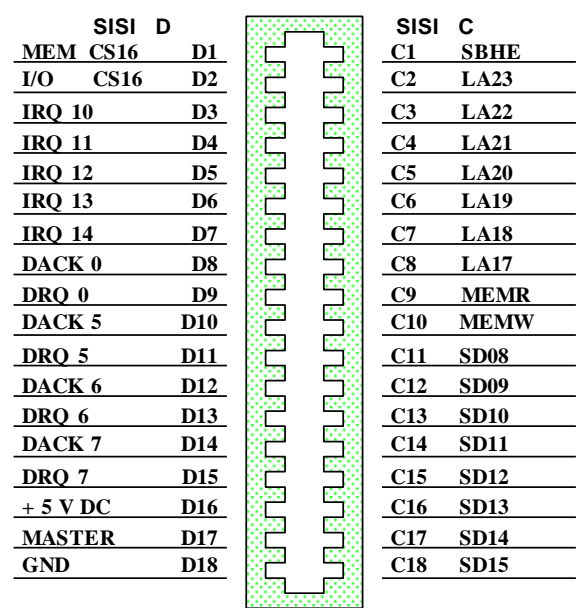

(b)

Gambar 1. Slot Perluasan IBM-PC (Arianto, 1994)

(a). Slot XT. (b). Slot tambahan untuk AT.

Pemakaian slot perluasan dalam berhubungan dengan PPI dapat digunakan 25 jalur. Jalur tersebut terdiri dari 8 jalur untuk bus data yakni D0 - D7, 1 jalur AEN, 1 Jalur GND, 1 jalur IOW, 1 jalur IOR, 1 jalur CLK, 1 jalur Vcc 5 volt, 1 jalur Reset, dan 10 jalur Bus Alamat.

Fungsi dari jalur-jalur tersebut adalah :

1. Saluran bus data (D0 - D7) nomor kaki penyemat (pin) A2 - A9. D0 menunjukkan bit dengan signifikasi terendah dan D7 menunjukkan bit dengan signifikasi tertinggi. Data bus merupakan jalur yang menyediakan pemindahan data antara memori pada mikrokomputer dan peralatan input/output secara dua arah.

2. AEN (Adress Enable) pada pin A11. Sinyal pada pin ini aktif pada status logika rendah (0) sebagai kendali penyedia alamat.

3. GND pada pin B1. Pin ini sebagai pentanahan (ground) dan penghubung untuk memberikan status logika rendah $(0)$.

4. Vec +5 pada pin B3. Pin ini sebagai penyedia catu daya (power Supply) dan penghubung untuk memberikan status logika tinggi.

5. IOW (I/O Write) pada pin B14. Keluaran pin ini merupakan sinyal yang aktif pada status logika rendah (0). Saat sinyal ini aktif maka bus alamat akan berisi alamat gerbang I/O dan bus data akan berisi data yang akan ditulisi.

6. IOR (I/O Read) pada pin B13. Sinyal keluaran pin ini aktif pada status logika rendah (0) dan menunjukkan kepada I/O bahwa siklus bus merupakan siklus baca dengan alamat yang ada pada bus alamat.

7. Reset pada pin B2. Pin ini aktif pada status logika tinggi (1).

8. Jalur Bus Alamat (A0 - A9) pada pin A22 - A31. Jalur ini digunakan untuk mengalamati peralatan I/O. A0 adalah bit dengan signifikan terkecil (LSB, least significant bit) dan A9 adalah bit dengan signifikansi terbesar (MSB, most significant bit).

Interface atau antarmuka merupakan rangkaian tambahan dalam menghubungkan komputer dengan peranti periferal seperti sensor atau alat lain yang dapat diprogram.

Interface digunakan untuk dialog antara prosesor dengan peralatan periferal. Jika prosesor akan membaca atau memberikan data dari/ke periferal, maka interface harus diaktifkan. Hal ini paling sederhana melalui sebuah alamat yang ada dalam interface. 


\subsection{PPI 8255}

PPI 8255 merupakan jenis IC (Integrated Circuit) yang digunakan sebagai komponen utama dalam PPI Card. Gambar 2 menunjukkan PPI 8255, yang mempunyai tiga port (A, B dan C) dan masing-masing dengan 8 sambungan. Setiap proses transmisi dapat disalurkan masing-masing 1 byte.

Tiap-tiap port PPI 8255 dapat bekerja sebagai port masukan maupun port keluaran. Fungsinya masingmasing ditentukan dengan memberikan kata kendali (word control) melalui bus data di komponen logika pengendali. Komponen hanya mempunyai 2 hubungan alamat (A0, A1). Dengan hubungan ini, beberapa lintasan data dapat dihubungi: port $\mathrm{A}, \mathrm{B}$ atau $\mathrm{C}$, dan register logika kendali yang menentukan fungsi komponen.

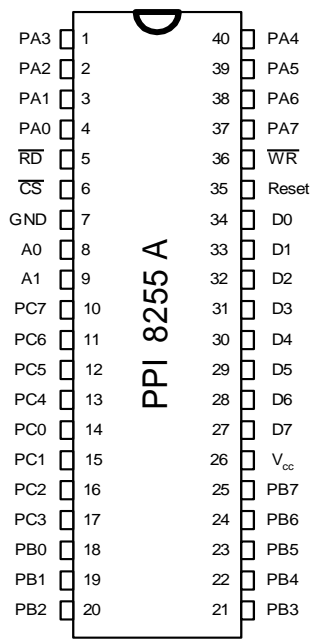

(a)

$\begin{array}{ll}\text { Keterangan pin: } \\ \text { D0 - D7 } & : \text { Bus data (dua arah) } \\ \text { RESET } & \text { : Masukan Reset } \\ \text { CS } & : \text { Memilih Chip } \\ \text { RD } & : \text { Masukan Baca } \\ \text { WR } & : \text { Masukan Tulis } \\ \text { A0, A1 } & : \text { Alamat Port } \\ \text { PA0 - PA7 } & : \text { Port A (bit } 0-7) \\ \text { PB0 - PB7 } & : \text { Port B (bit } 0-7) \\ \text { PC0 - PC7 } & : \text { Port C (bit } 0-7) \\ \text { Vcc } & : \text { Tegangan Catu }(+5 \mathrm{~V}) \\ \text { GND } & : \text { Ground }(0 \text { V) }\end{array}$

(b)

Gambar 2. Komponen IC PPI 8255 (Wolfgang, 1993)

(a). Konfigurasi pin (b). keterangan pin

Hal pertama yang dilakukan adalah menentukan alamat yang akan dipakai untuk berhubungan dengan interface. Untuk ini diambil rentang alamat yang ada pada PC, yang disediakan untuk kartu (card) prototip, yaitu $300 \mathrm{H}$ hingga 31FH. Cakupan alamat ini mengandung 32 buah alamat yang mungkin. Untuk interface 8255 dibutuhkan 4 buah alamat. Misalnya, dalam bentuk biner alamat 300H hingga 303H adalah 1100000000 hingga 1100000011. Bobot paling rendah, bit A0 dan A1, dihubungkan langsung dengan masukan alamat pada 8255 , sisanya harus didekode (Wolfgang, 1993).

Hal-hal yang menentukan untuk mengatur proses peralihan data seluruh ragam kerja dari PPI 8255 antara lain :

CS : Bila diberi logika rendah, PIO akan aktif.

RD : Bila diberi logika rendah, PIO siap dibaca oleh CPU.

WR : Bila diberi logika rendah, PIO siap menerima data atau perintah dari CPU

Reset : Bila diberi logika tinggi, data pada register pengendali akan dihapus dan semua port diset sebagai masukan.

A0-A1 : Terminal yang digunakan untuk memilih salah satu dari port atau register.

D0-D7 : Penyangga saluran data untuk menaikkan tarif data (menjaga keadaan data agar tidak berubah) yang melewati saluran data.

Susunan port dari 8255 ke alamat-alamat yang dipilih ditunjukkan pada tabel 1 .

Tabel 1. Contoh cara pendekodean alamat port pada PPI 8255

\begin{tabular}{|c|c|c|c|c|}
\hline \multirow{2}{*}{$\mathrm{A} 0$} & \multirow{2}{*}{ A1 } & \multirow{2}{*}{ Arah data } & \multicolumn{2}{|c|}{ Alamat } \\
\hline & & & Heksa & Desimal \\
\hline 0 & 0 & Bus data $\leftrightarrow$ Port $\mathrm{A}$ & 300 & 768 \\
\hline 0 & 1 & Bus data $\leftrightarrow$ Port $\mathrm{B}$ & 301 & 769 \\
\hline 1 & 0 & Bus data $\leftrightarrow$ Port $\mathrm{C}$ & 302 & 770 \\
\hline 1 & 1 & Bus data $\leftrightarrow$ Logika kendali & 303 & 771 \\
\hline
\end{tabular}


Alamat-alamat tersebut hanya berlaku dalam pendekodean dari $300 \mathrm{H}-303 \mathrm{H}$. Pembuatan program 8255 berlangsung dengan memberikan kata kendali pada komputer, digunakan untuk memfungsikan Port A, Port B, dan Port C sebagai masukan atau keluaran (Wolfgang, 1993).

\section{Metodologi}

\section{Metodologi yang digunakan dapat dibedakan menjadi 2 tahap yaitu}

1. Tahap Perancangan dan Pembuatan Dengan dasar teori yang ada, dilakukan perancangan dan pembuatan perangkat keras (hardware) dan perangkat lunak (software) yang saling terintegrasi sehingga dapat dihasilkan alat uji yang sesuai dengan yang dibutuhkan.

2. Tahap Pengujian

Alat yang sudah jadi kemudian diuji untuk mengetahui kemampuannya dalam melakukan deteksi kerusakan pada PPI card.

\subsection{Tahap Perancangan dan Pembuatan}

Perancangan alat uji PPI Card ini dapat digambarkan dalam blok diagram seperti pada gambar 3.

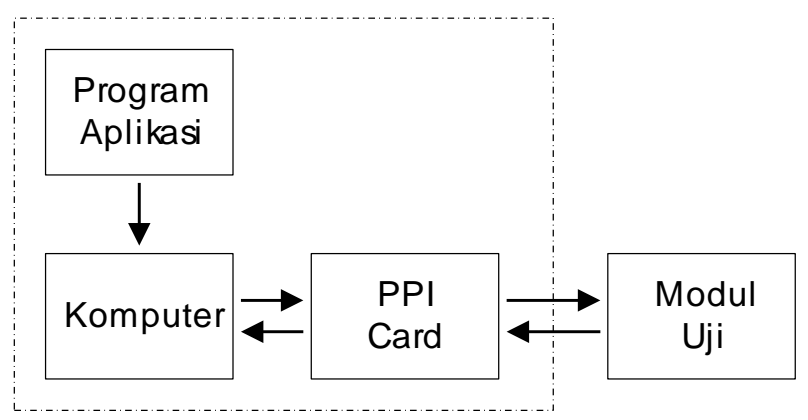

Gambar 3. Blok diagram alat uji PPI Card

Berdasarkan gambar blok diagram di atas, target penelitian ini adalah program aplikasi (software) dan modul uji (hardware). Program aplikasi digunakan untuk sebagai pengendali komputer untuk 'berkomunikasi' dengan modul uji melalui PPI Card, sehingga komputer dapat membaca sinyal masukan dari modul uji dan mengirim sinyal keluaran ke modul uji.

Perancangan dan pembuatan alat uji PPI Card dibedakan menjadi dua, yaitu perangkat keras (hardware) dan perangkat lunak (software). Perangkat keras yang dihasilkan berupa modul uji PPI card, yang harus dihubungkan dengan PPI card yang akan diuji, sedangkan perangkat lunaknya ditulis dengan menggunakan bahasa pemrograman Delphi, yang menghasilkan program aplikasi yang dijalankan pada komputer untuk sistem operasi Win9X/WinME/WinXP.

\subsubsection{Perancangan dan Pembuatan Perangkat Keras}

Perancangan dan pembuatan perangkat keras berupa modul uji PPI Card dimulai dengan merancang skema rangkaian modul uji seperti pada gambar 4. 


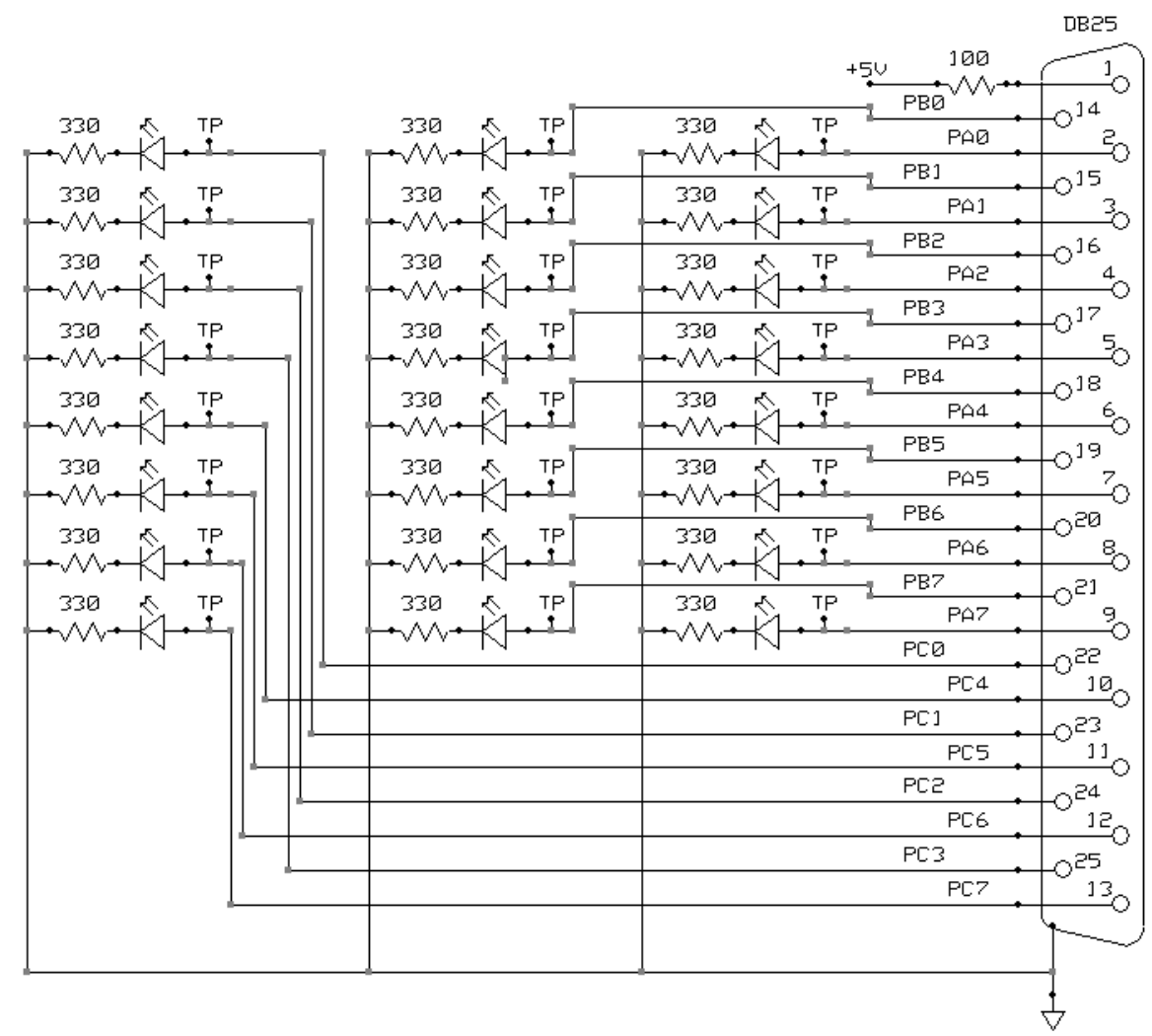

Gambar 4. Skema rangkaian modul uji PPI card

Gambar 4 menunujukkan skema rangkaian modul uji PPI card. Rangkaian ini menggunakan LED (Light Emitting Diode) dan dilengkapi TP (Test Point). LED digunakan untuk pengujian port-port PPI sebagai keluaran (output), sedangkan TP digunakan untuk pengujian port-port PPI sebagai masukan (input). Jumlah LED yang digunakan adalah 24 buah untuk tiga port PPI, dimana masing-masing port menggunakan 8 buah LED. Untuk membedakan antara port $\mathrm{A}$, port $\mathrm{B}$ dan port $\mathrm{C}$ maka digunakan LED dengan warna yang berbeda. LED warna merah untuk port A, LED warna kuning untuk port B dan LED warna hijau untuk port C. Sedangkan jumlah TP juga 24 buah (1 buah untuk masing-masing port), yang dipasang didekat LED.

Berdasarkan rancangan skema rangkaian, dibuat rancangan PCB (Printed Circuti Board - Papan Rangkaian Tercetak) untuk Modul uji PPI Card seperti pada gambar 5.

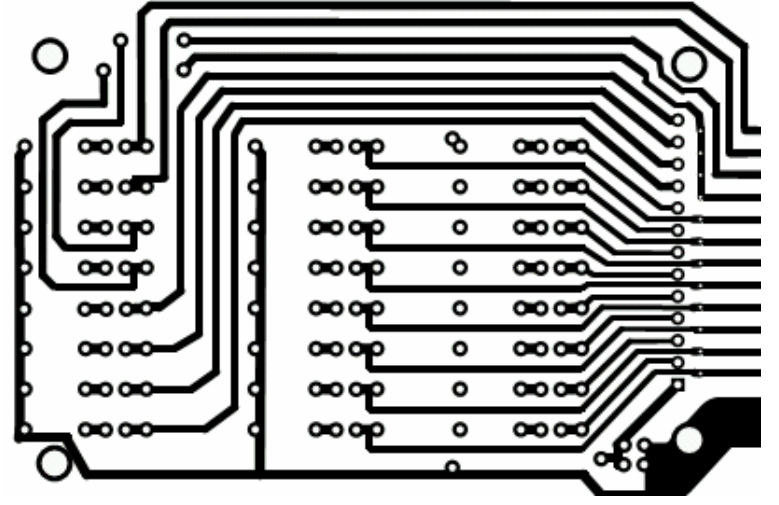

(a). Layout PCB (bottom layer)

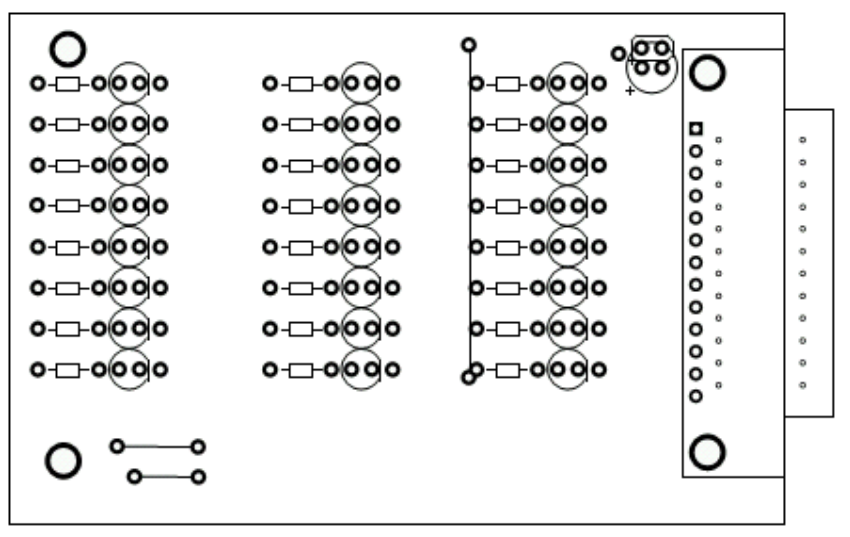

(b). Tata letak komponen

Gambar 5. Rancangan PCB Modul uji PPI card

Sedangkan untuk proses pembuatan dimulai dari pembuatan PCB, yang diikuti dengan pemasangan komponen. 


\subsubsection{Perancangan dan Pembuatan Perangkat Lunak}

Perancangan dan pembuatan perangkat lunak dilakukan dengan menggunakan bahasa pemrograman Delphi, yang menghasilkan program aplikasi yang dijalankan pada komputer untuk sistem operasi Win9X/WinME/WinXP.

\subsection{Tahap Pengujian}

Proses pengujian dapat dibedakan menjadi dua. Pengujian pertama dilakukan pada perangkat keras (hardware) untuk memastikan modul uji PPI card telah dibuat sesuai. Sedangkan pengujian kedua dilakukan pada program aplikasi (software).

\section{HASIL DAN PEMBAHASAN}

Hasil penelitian ini dapat dibedakan menjadi dua, yaitu perangkat keras (hardware) dan perangkat lunak (software). Perangkat keras yang dihasilkan berupa modul uji PPI card, yang harus dihubungkan dengan PPI card yang akan diuji, sedangkan perangkat lunaknya ditulis dengan menggunakan bahasa pemrograman Delphi, yang menghasilkan program aplikasi yang dijalankan pada komputer untuk sistem operasi Win9X/WinME/WinXP.

\subsection{Perangkat Keras (Hardware)}

Gambar 4menunujukkan skema rangkaian modul uji PPI card. Rangkaian ini menggunakan LED (Light Emitting Diode) dan dilengkapi TP (Test Point). LED digunakan untuk pengujian port-port PPI sebagai keluaran (output), sedangkan TP digunakan untuk pengujian port-port PPI sebagai masukan (input). Jumlah LED yang digunakan adalah 24 buah untuk tiga port PPI, dimana masing-masing port menggunakan 8 buah LED. Untuk membedakan antara port $\mathrm{A}$, port $\mathrm{B}$ dan port $\mathrm{C}$ maka digunakan LED dengan warna yang berbeda. LED warna merah untuk port A, LED warna kuning untuk port B dan LED warna hijau untuk port C. Sedangkan jumlah TP juga 24 buah (1 buah untuk masing-masing port), yang dipasang didekat LED.

Semua komponen dalam rangkaian kemudian dirangkai dalam sebuah PCB sebagaimana ditunjukkan pada gambar

6

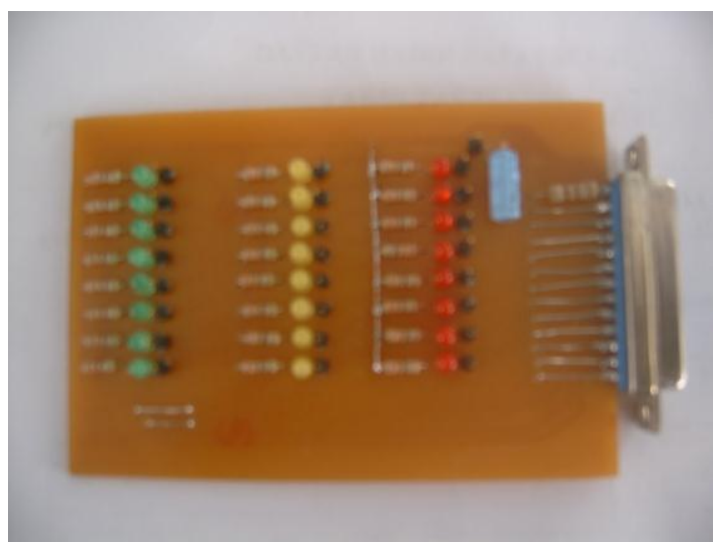

(a). tampak depan

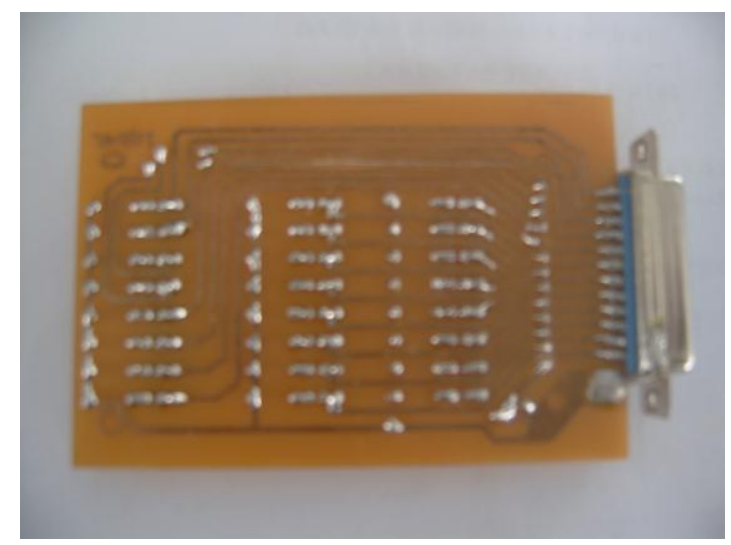

(b). tampak belakang

Gambar 6 Modul uji (hardware) PPI card

\subsection{Perangkat Lunak (Software)}

Software yang dibuat dalam bahasa pemrograman Delphi menghasilkan program aplikasi, yang diberi nama Uji_PPI.exe. Program aplikasi ini dibuat bersama dengan hardware modul uji PPI card, artinya untuk menjalankan program aplikasi Uji_PPI.exe harus bersamaan dengan menghubungkan modulnya ke komputer melalui PPI card. Penjelasan tampilan program aplikasi Uji_PPI.exe sebagaimna gambar 7adalah sebagai berikut: 


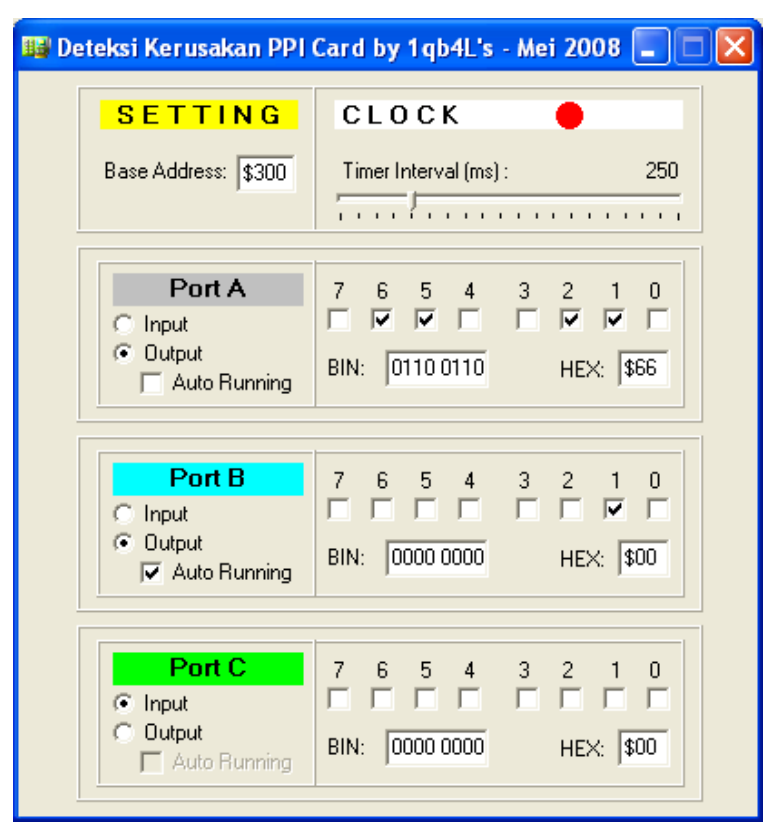

Gambar 7 Tampilan program Uji_PPI.exe

Pada Bagian SETTING, terdapat informasi bahwa PPI card yang dipasang di slot ISA komputer harus diset pada base address (alamat dasar) \$300. Jika PPI card tidak diset pada base address $\$ 300$, maka bisa berakibat program Uji_PPI.exe tidak dapat terhubung dengan modul uji.

Pada bagian CLOCK, terdapat LED yang berkedip berdasarkan interval waktu yang bisa diatur dengan menggeser track bar, minimal $50 \mathrm{~ms}$ (milisecond) dan maksimal $1000 \mathrm{~ms}$. CLOCK ini menentukan kecepatan pada pengujian port sebagai keluaran (output) dengan menggunakan mode auto running, dimana LED pada bagian output akan menyala satu per satu secara bergantian dari bit LSB (Least Significant Bit) sampai dengan bit MSB (Most Significant Bit) dan berulang.

Pada gambar 6 menunjukkan Port A diset pada mode output, dimana port PA1 (bit1), PA2, PA5 dan PA6 diset dalam kondisi high (logika 1); Port B juga diset pada mode output tetapi menggunakan auto running, dimana LED pada bagian output akan menyala satu per satu secara bergantian; sedangkan untuk Port $\mathrm{C}$ diset mode input, dimana tampilan untuk masing-masing port bergantung kondisi masukan Port B pada hardware modul uji PPI.

\subsection{Pengujian}

Pengujian pertama dilakukan pada hardware untuk memastikan modul uji PPI card telah dibuat sesuai. Sedangkan pengujian kedua dilakukan pada program aplikasi (software).

\subsubsection{Pengujian Hardware}

Pengujian hardware dilakukan melalui dua tahap, yaitu tahap pertama dengan membuat semua port PPI sebagai input dan tahap kedua dengan membuat semua port PPI sebagai output. Pada masing-masing tahap ini kemudian diukur tegangan untuk tiap-tiap port. Hasil dari pengujian diperlihatkan pada tabel 2 dan tabel 3 .

Tabel 2. Pengujian hardware port PPI sebagai input

\begin{tabular}{|c|c|c|c|c|c|}
\hline Pin & $\mathrm{V}_{\text {pin }}$ & Pin & $\mathrm{V}_{\text {pin }}$ & Pin & $\mathrm{V}_{\text {pin }}$ \\
\hline PA.0 & 3.88 & PB.0 & 4.17 & PC.0 & 4 \\
\hline PA.1 & 3.93 & PB.1 & 4.19 & PC.1 & 3.96 \\
\hline PA.2 & 3.9 & PB.2 & 4.19 & PC. 2 & 3.9 \\
\hline PA.3 & 3.94 & PB.3 & 4.2 & PC.3 & 4.03 \\
\hline PA.4 & 3.93 & PB.4 & 4.2 & PC.4 & 4.67 \\
\hline
\end{tabular}




\begin{tabular}{|c|c|c|c|c|c|}
\hline PA.5 & 3.94 & PB.5 & 4.21 & PC.5 & 3.99 \\
\hline PA.6 & 3.95 & PB.6 & 4.2 & PC.6 & 4.07 \\
\hline PA.7 & 4 & PB.7 & 4.19 & PC.7 & 4.15 \\
\hline
\end{tabular}

Pengujian Port PPI sebagai input dilakukan dengan mengeset port PPI card sebagai input melalui, kemudian $+5 \mathrm{~V}$ pada modul uji dihubungkan ke masing-masing TP (Test Point) port, dan diukur tegangannya. Hasil pengujian Port PPI sebagai input menunjukkan bahwa nilai rata-rata $=4,07$ Volt dengan nilai minimal $=3,88$ Volt dan nilai maksimal $=4,67$ Volt. Tegangan maksimal tidak bisa mencapai $\mathrm{V}_{\mathrm{CC}}(5$ Volt $)$ karena adanya resistor seri $100 \Omega$, tetapi range tegangan input diatas sudah memenuhi sebagai tegangan masukan kondisi high sesuai dengan datasheet IC PPI card $\left(\mathrm{V}_{\mathrm{IH}}\right)$, yaitu berada pada range 2 Volt sampai dengan $\mathrm{V}_{\mathrm{CC}}$ (tegangan sumber).

Tabel 3. Pengujian hardware port PPI sebagai output

\begin{tabular}{cc}
\hline Pin & $\mathrm{V}_{\text {pin }}$ \\
\hline \hline PA.0 & 4.41 \\
\hline PA.1 & 4.39 \\
\hline PA.2 & 4.42 \\
\hline PA.3 & 4.36 \\
\hline PA.4 & 4.37 \\
\hline PA.5 & 4.44 \\
\hline PA.6 & 4.38 \\
\hline PA.7 & 4.37 \\
\hline
\end{tabular}

\begin{tabular}{rr}
\hline Pin & \multicolumn{1}{c}{$\mathrm{V}_{\text {pin }}$} \\
\hline \hline PB.0 & 4.25 \\
\hline PB.1 & 4.28 \\
\hline PB.2 & 4.3 \\
\hline PB.3 & 4.29 \\
\hline PB.4 & 4.31 \\
\hline PB.5 & 4.3 \\
\hline PB.6 & 4.31 \\
\hline PB.7 & 4.3 \\
\hline
\end{tabular}

\begin{tabular}{rr}
\hline Pin & $\mathrm{V}_{\text {pin }}$ \\
\hline \hline PC.0 & 4.36 \\
\hline PC. 1 & 4.38 \\
\hline PC. 2 & 4.39 \\
\hline PC. 3 & 4.39 \\
\hline PC. 4 & 4.31 \\
\hline PC.5 & 4.2 \\
\hline PC. 6 & 4.21 \\
\hline PC. 7 & 4.22 \\
\hline
\end{tabular}

Pengujian Port PPI sebagai input dilakukan melalui program dengan mengeset port PPI card sebagai output dalam kondisi high untuk semua port, kemudian dilakukan pengukuran tegangan masing-masing port pada modul uji. Hasil Pengujian Port PPI sebagai input menunjukkan bahwa nilai rata-rata $=4,33$ Volt dengan nilai minimal $=4,2$ Volt dan nilai maksimal $=4,44$ Volt. Range tegangan output diatas sudah memenuhi sebagai tegangan keluaran kondisi high sesuai dengan datasheet IC PPI card $\left(\mathrm{V}_{\mathrm{OH}}\right)$, yaitu minimal 3 Volt.

\subsubsection{Pengujian Software}

Untuk pengujian kedua yaitu untuk program aplikasi (software), juga dilakukan dalam dua tahap, yaitu tahap pertama dengan membuat semua port PPI sebagai input dan tahap kedua dengan membuat semua port PPI sebagai output. Pada masing-masing tahap ini kemudian dibandingkan antara tampilan program aplikasi di layar monitor dengan keadaan indikator LED pada modul uji PPI. Karena yang dilakukan adalah pengujian software, sebelumnya telah dipastikan bahwa PPI Card yang digunakan dalam keadaan baik.

Pengujian port PPI sebagai input dilakukan dengan mengeset port PPI card sebagai input melalui program aplikasi, kemudian $+5 \mathrm{~V}$ pada modul uji dihubungkan ke pada salah satu TP (Test Point) port, misalnya TP untuk port PC1 (port $\mathrm{C}$ bit 1 ) pada modul uji PPI seperti pad gambar 8

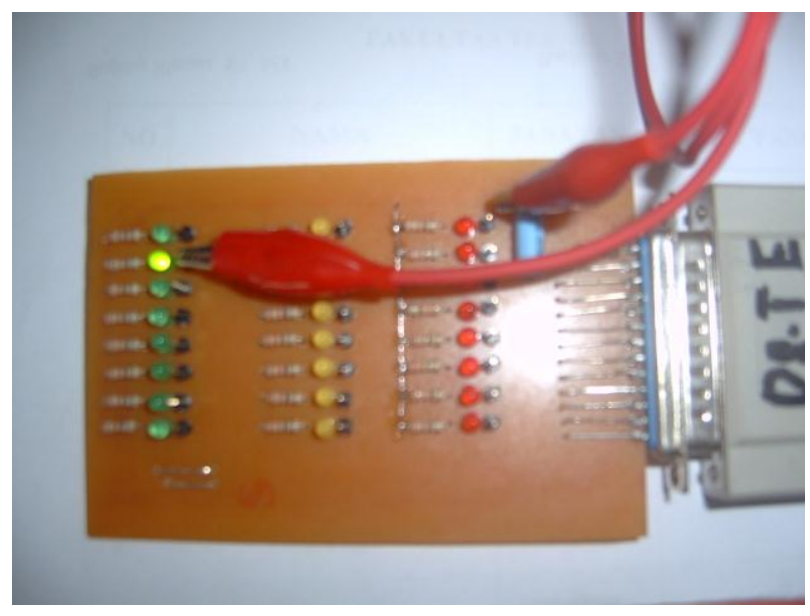


Gambar 8 Kondisi modul uji dalam pengujian PPI Card sebagai input

Pengaruh masukan dari modul uji ini (pada gambar 8) terlihat bahwa tampilan program aplikasi di layar monitor menunjukkan perubahan pada checkbox 1 untuk Port $\mathrm{C}$, dari kondisi uncheck menjadi check yang berartu kondisi high (logika 1) seperti pada gambar 9. Tampilan program aplikasi ini sesuai dengan kondisi hardware modul uji, sehingga program aplikasi untuk pengujian ini berhasil sesuai yang diinginkan.

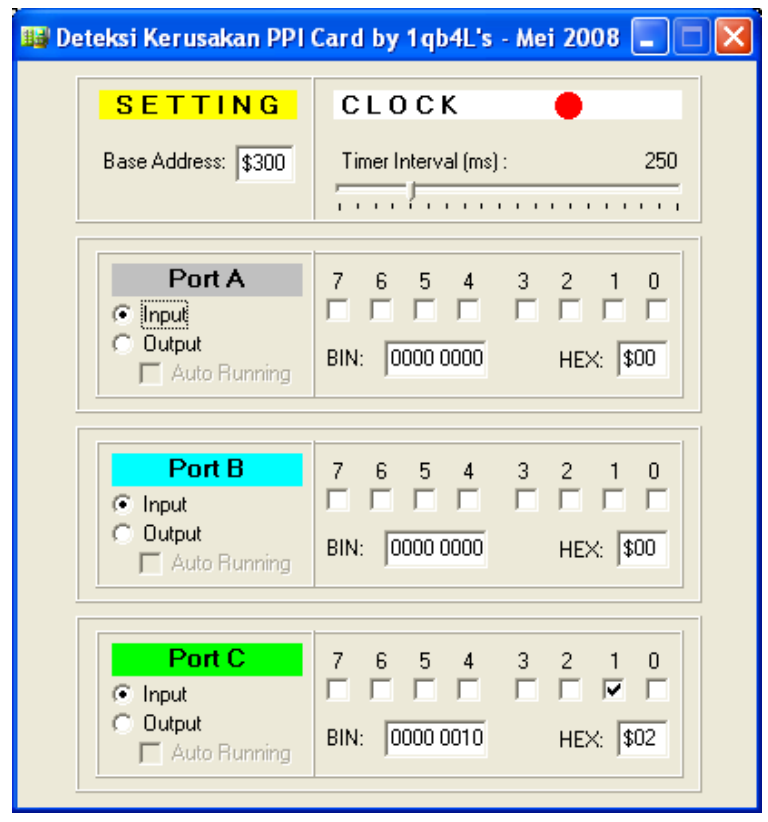

Gambar 9 Tampilan software dalam pengujian PPI Card sebagai input

Selanjutnya pengujian Port PPI sebagai input dilakukan melalui program dengan mengeset port PPI Card sebagai output dalam kondisi high, kemudian untuk beberapa port dibuat kondisi high dengan mengklik pada checkbox yang sesuai port-port tersebut sesuai dengan gambar 10 .

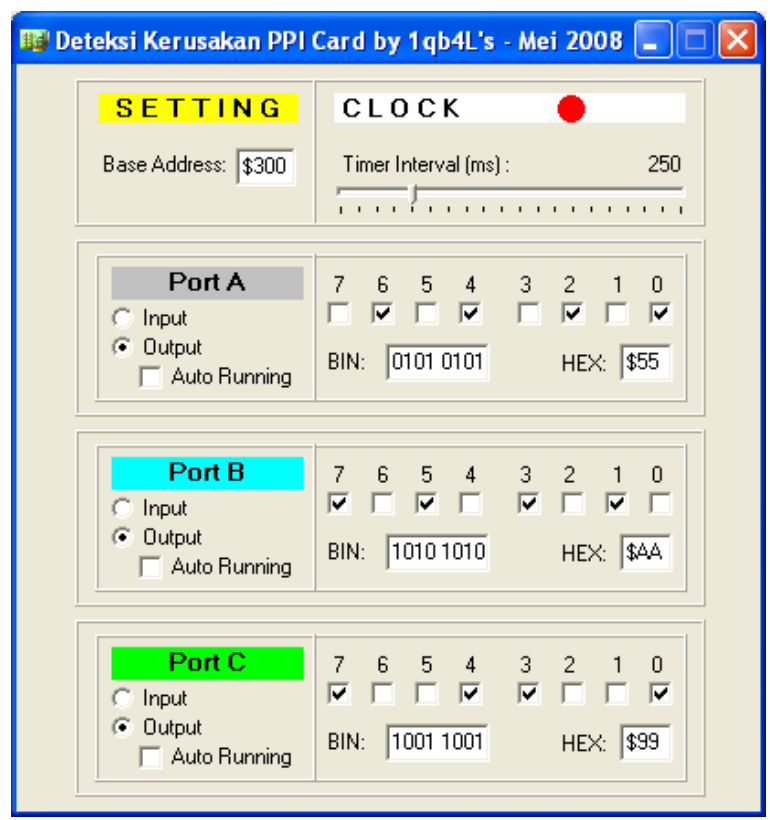

Gambar 10. Tampilan software dalam pengujian PPI Card sebagai output

Pengaruh dari pengesetan program aplikasi pada gambar 10, nampak bahwa hardware modul uji menunjukkan perubahan seperti pada gambar 11 mana untuk port-port yang diset pada kondisi high (check) pada program aplikasi, maka LED pada hardware modul uji menyala. Kondisi hardware modul uji ini sesuai dengan tampilan program aplikasi ini, sehingga program aplikasi untuk pengujian ini berhasil sesuai yang diinginkan 


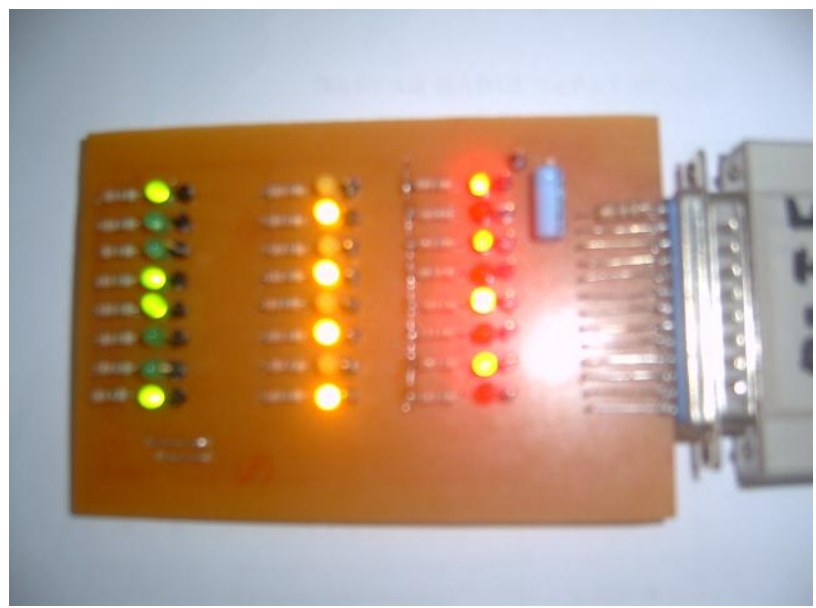

Gambar 11. Kondisi modul uji dalam pengujian PPI Card sebagai output

\section{KESIMPULAN}

Berdasarkan hasil penelitian ini, dapat disimpulkan hal-hal sebagai berikut:

1. Telah dapat dibuat modul uji PPI card dan perangkat lunaknya untuk pengujian rusak dan tidaknya PPI card yang terpasang di komputer.

2. Sebagai keluaran (output), PPI dikatakan rusak total atau sebagaian port-nya jika LED yang menyala pada modul uji tidak sesuai dengan tampilan program aplikasi Uji_PPI.exe di layar monitor (checkbox).

3. Sebagai masukan (input), PPI dikatakan rusak total atau sebagaian port-nya jika TP dihubungkan dengan tegangan +5 Volt pada modul uji dan tidak terjadi perubahan pada tampilan program aplikasi Uji_PPI.exe di layar monitor (checkbox).

\section{DAFTAR PUSTKA}

[1] , 1996, HARRIS Semiconductor Datasheet : 82C255A - CMOS Programmable Peripheral Interface.

[2] , 1995, INTEL Datasheet : 82C255A - CHMOS Programmable Peripheral Interface.

[3] Arianto widyanto, Haryono Eduard \& Fendy, 1994, Belajar Mikroprosesor dan Mikrokontroler Melalui Komputer PC, PT Elek Media Komputindo, Jakarta

[4] Malvino A.P., 1985, Prinsip-prinsip Elektronika Jilid 1, Penerbit Erlangga, Jakarta

[5] Malvino A.P., 1996, Elektronika Komputer Digital: Pengantar Mikrokomputer, Alih Bahasa : Tjia May On, Penerbit Erlangga, Jakarta

[6] Martina, Inge, 2000, 36 Jam Belajar Komputer Delphi 5.0., Gramedia, Jakarta.

[7] Wasito S., 2001, Vademekum Elektronika, PT. Gramedia Pustaka Utama, Jakarta.

[8] Wolfgang Link, 1993, Pengukuran, Pengendalian dan Pengaturan dengan PC, PT. Elex Media Komputindo, Jakarta. 